\title{
THE EFFECT OF JOJOBA OIL -DIESEL FUEL BLENDS ON COMBUSTION AND EXHAUST GASES EMISSIONS FOR TRACTOR DIESEL ENGINES
}

\section{Samy M. Younis ${ }^{1}$, Mohamed S. Omran ${ }^{2}$ and Mahdy S. Mahdy ${ }^{3}$ \\ ABSTRACT}

Experiments were designed to study the effect of blends of jojoba oil with diesel fuel on tractor emission characters. Exhaust gases emission tests were conducted for agricultural tractor running on the 0, 20, 40, 60 and $80 \%$ jojoba-diesel fuels as compared to pure petroleum diesel fuel under typical field tillage operation at different forward speeds $(1.75,2.60$ and $4.85 \mathrm{~km} / \mathrm{h}$ ).

The chemical analysis of Jojoba oil revealed that it contains law carbon atoms and oxygen atoms in its chemical structure, so it produced complete combustion and decreased the emitted toxic gases which lower environmental pollution because it is an oxidizing agent.

The increase in jojoba oil blended ratio more than $20 \%$ leads to increase fuel viscosity which decreases the engine power and incomplete combustion which leads to increase environmental pollution.

The utilization of jojoba-diesel blend $20 \%$ (J20) gave significant reduction in total hydrocarbon (THC), carbon dioxide $\left(\mathrm{CO}_{2}\right)$, carbon monoxide $(\mathrm{CO})$, Sulfur dioxide $\left(\mathrm{SO}_{2}\right)$ and nitrogenous oxides $\left(\mathrm{NO}_{x}\right)$ gases emissions, which have positive effect on environment.

Using jojoba oil blend 20\% (J20) improved the combustion efficiency to $80 \%$ at tractor forward speeds, which gave better performance of the tractor engine and decreased emission of toxic gases.

Key words: Jojoba oil, Diesel engines, Alternative fuel, Exhaust emissions.

1. Prof., Agric. Eng. Dept., Fac. of Agric., Cairo University.

2. Assoc. Prof., Agric. Eng. Dept., Fac. of Agric., Cairo University.

3. Demonstrator, Agric. Eng. Dept., Fac. of Agric., Cairo University. 


\section{INTRODUCTION}

7 he world is presently confronted with three dramatic crises of growing energy demand, raising food prices, and environmental

degradation. These crises are attributed to four dilemmas simultaneously colliding, all resulting from the patterns of increasing consumption and near depleting reserves of fossil fuels.

Jojoba oil has become one of the most genuinely Egyptian products (Salem, 2000). Jojoba oil and its derivatives have found different applications and are used in fields of cosmetics, pharmaceuticals and lubricants.

Research work over the last few decades has greatly expanded our knowledge of how to recognize and meat renewable energy requirements. However, the industry's adoption of biodiesel has probably has greatest impact on use efficiency of plant biodiesel.

The triggering factors have spurred scientific community to interest in looking for alternative fuel sources and renewable energy to be supportive for the provision of basic human needs from liquid fuels and also achieve food and energy security as well as the protecting and preservation of the environment (World Energy Outlook 2016). Therefore the renewable energy including biofuel had and still have a vital role in achieving the objectives of sustainable development at the global level and in particular Egypt (INP, 2008).

Using vegetable oils as a fuel for diesel engines is a must ( Tahir et al. 1982). However, despite the technical feasibility, vegetable oil as fuel could not get acceptance, as they were more expensive than petroleum fuels (Peterson et al , 1983, Peterson, 1986, Pramanik,2003 and Ramadhas et al. 2004). Later the various factors as stated earlier, created renewed interest of researchers in vegetable oil as substitute fuel for diesel engines. (Alton et al. 2001) and (Herchel et al. 2001) used vegetable oils such as sunflower, peanut oil, soybean oil, Jatropha and their derivatives as alternative fuel. The recent upward trend in oil prices due to suspicion in outfit of petroleum products shortage and eventually depletion has a great impact on economy that has to look for alternatives to incur the growth rate (Demirbas, 2007). 
Development of sources of biofuels could be a major milestone in Egypt's efforts to harness available energy resources, and promote the use of renewable energy as a long-term strategy to mitigate the effects of climate change.

The aim of this study is to investigate the optimum jojoba oil percentage in the petroleum diesel that can be used with tractor diesel engines and reduce the emission of exhaust toxic gases.

\section{Combustion and exhaust emissions of diesel engine}

Diesel engine emissions firstly depend on the engine design and operating conditions. Of course fuel property is very affective on the composition of exhaust emissions. Fig. (1) shows the formation of emissions for complete and incomplete combustions.

The emission of gases and particles covered by legislation are produced by incomplete combustion which are:

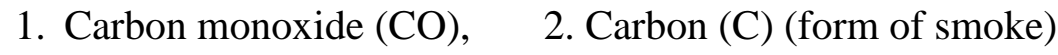

3. Total hydrocarbons (THC)

4. Nitrogen monoxide (NO) and nitrogen dioxide (NO2), considered as NOx. (Martyr and Plint, 2007)

Emission formation also depends on the design of combustion chamber and injectors. Soot and unburned hydrocarbons are formed during premixing and mixing control phases. Formation of NOx is depending on combustion temperature and mixture ratio. Combustion temperature should exceed $1800 \mathrm{~K}$ for the formation of NOx. The mixture has much more oxygen concentration which means that particle matter and hydrocarbons formation rate are reduced.

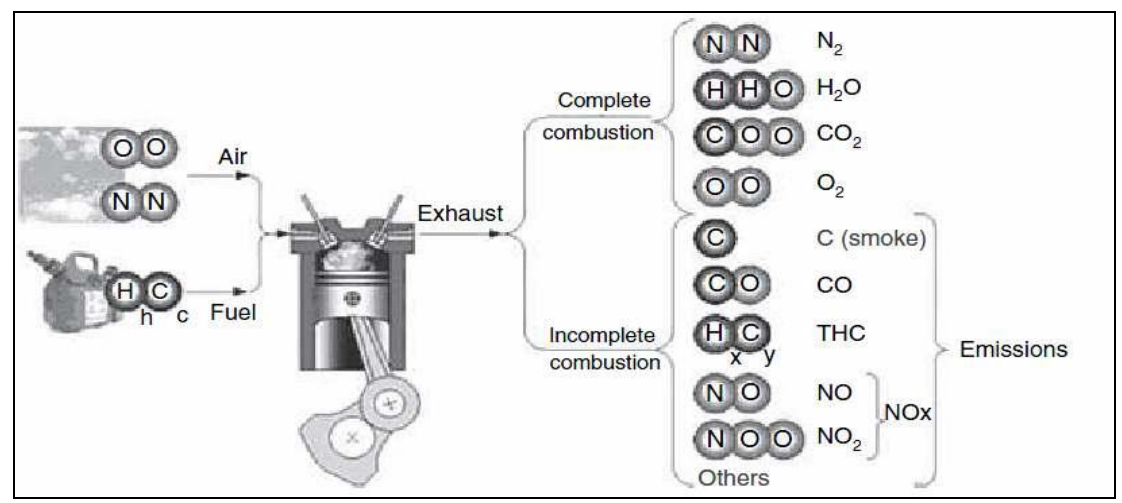

Fig. 1. Gaseous components of combustion processes 


\section{MATERIALS AND METHODS}

\section{MATERIALS}

\section{Jojoba oil}

Jojoba oil consists mainly of $\mathrm{C}_{20: 1}(70.7 \%), \mathrm{C}_{22: 1}(14.1 \%)$, palmitic acid $(1.6 \%)$, oleic acid $(11.2 \%)$ and $\mathrm{C}_{24: 1}(1.6 \%)$. Jojoba oil composed mainly of straight chain monoesters of $\mathrm{C}_{20}$ and $\mathrm{C}_{22}$ acids and alcohols with two double bonds.

Jojoba oil is almost free of oil triglycerides which indicate that jojoba oil is different from all known oilseed crops since it is not a fat but a liquid ester wax. Therefore, jojoba oil is unique non edible oil among other plant oils. The oil wax is a mixture of compounds. Each compound is made from 3 elements - carbon, hydrogen and oxygen. One of the compounds in the mixture has the formula $\mathrm{C}_{42} \mathrm{H}_{80} \mathrm{O}_{2}$. It has 42 carbon atoms, 80 hydrogen atoms and 2 oxygen atoms strongly joined together.

\section{Fuel blends preparation}

Blending of jojoba oil with diesel fuel was prepared in the laboratory. Different blend ratios were selected for measurements and evaluation. These blend ratios were $0,20,40,60$ and 80 percent by volume of jojoba oil in a mixture of jojoba oil and diesel fuel. They are referred to as blends jojoba oil with diesel fuel of J0, J20,J40, J60, and J80 respectively. These abbreviations are adopted throughout the present study.

Jojoba oil was analyzed to determine physical characteristics according to American Society for Testing and Materials (ASTM, 2008). The physical characteristics of jojoba oil were compared with pure diesel fuel and its blends with diesel fuel.

\section{b. Experimental Equipment}

\section{Tractor}

Tractor diesel engine performance tests were carried out in tractors and agricultural machinery testing station in agricultural engineering research Institute. Some technical specifications of the tested tractor are presented in Table (1).

\section{2-Exhaust emissions measurement}

Emissions tests were conducted for agricultural tractor running on different jojoba oil blends with diesel fuel under typical field tillage operation. The test unit was tractor and mounted 9-shank chisel plough. 
The unit was operated at three forward speeds $(1.75,2.60,4.85 \mathrm{~km} / \mathrm{h})$ in a clay soil where the plot area was $300 \times 36 \mathrm{~m}$. The sample probe of the gas analyzer was put in tail pipe of the tractor test unit. First the test unit was running with no-load at engine speed $2000 \mathrm{rpm}$.

The measurements of the tractor exhaust gaseous emissions were carried out in Cairo University Center for Environmental Hazard Mitigation (CEHM), using a Land Instruments Lancom Series III portable flue gas analyzer as shown in Fig. (2).

Table (1). Technical specifications of the tested tractor

\begin{tabular}{ll}
\hline Model & Helwan 35-IMT \\
\hline Type of engine & Four stroke, direct injection, \\
& naturally aspirated, air-cooled \\
Engine power, $\mathrm{kW}$ & 27.20 \\
Rated Engine speed ,rpm & 2700 \\
Compression ratio & $17: 1$ \\
Number of cylinders & 3 \\
Bore $\times$ stroke , mm & $105 X$ 125 \\
Injection pump & In-Line Injection Pump \\
\hline
\end{tabular}

The portable gas analyzer is capable of measuring total hydrocarbon (THC), carbon dioxide $\left(\mathrm{CO}_{2}\right)$, carbon monoxide $(\mathrm{CO})$, Sulfur dioxide $\left(\mathrm{SO}_{2}\right)$, nitrogen oxides (NOx), and oxygen $\left(\mathrm{O}_{2}\right)$. It also measures and displays the ambient air temperature, exhaust gas temperature and combustion efficiency. Exhaust gases concentrations for $\mathrm{NOx}, \mathrm{SO}_{2}, \mathrm{CO}$, and THC were measured in units of ppm, while $\mathrm{CO}_{2}$ and $\mathrm{O}_{2}$ were measured in percentage. The unit has $\pm 2 \%$ accuracy.

The exhaust gas samples were taken from $40 \mathrm{~mm}$ diameter tailpipe downstream of the exhaust manifold into the analyzer via a sample probe connected to the input connection on the back of the analyzer. All the parameters of exhaust gases emissions were measured instantaneously in real time as spot readings at one hour. Each reading was an average of three spot measurements. The exhaust gases measurements were performed during typical working day for the following operations:

1. The test unit running without load.

2. The test unit running on first gear, second gear and third gear for tillage operation at $1.75,2.6$ and $4.85 \mathrm{~km} / \mathrm{h}$, respectively. 


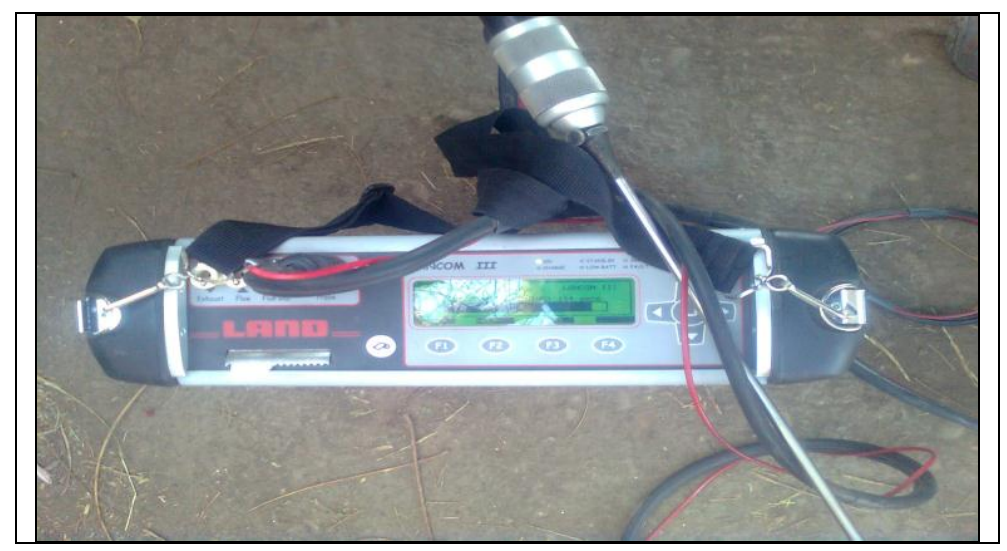

Fig.2. portable gas analyzer

\section{RESULTS AND DISCUSSION \\ Effect of jojoba oil-diesel blends ratio on exhaust gases}

The effect of the jojoba-diesel blends ratio on a tractor exhaust gases emissions were studied by using blends of 20,40 , and $60 \%$. The ratio $80 \%$ was discarded because it increases the blend viscosity which caused distribution in atomizing jojoba-diesel fuel. The parameters of the tractor gases emissions were measured using jojoba blends and compared with using $100 \%$ diesel fuel at three forward speeds under typical field tillage operation. The exhaust gases analysis are discussed as follows.

\section{Exhaust gas temperature}

Fig. (3) shows the increase in the exhaust gas temperature with increasing forward speed of the tractor. The exhaust gas temperature reflects the status of combustion inside the combustion chamber. In all cases, the exhaust gas temperature decreased with increasing the percentage by volume of the jojoba oil in the fuel blends.

The highest value of exhaust gas temperature of $397{ }^{\circ} \mathrm{C}$ was observed with the diesel fuel at the second forward speed of tractor $(2.6 \mathrm{~km} / \mathrm{h})$. On the other hand, value with $\mathrm{J} 60$ was $320^{\circ} \mathrm{C}$ only.

The reduction in the exhaust gas temperature for the jojoba blends may be attributed to the lower calorific value of jojoba oil comparing with that of pure diesel therefore, increasing the percentage of jojoba oil in blend decreased the calorific value of the blend which results in reducing heat release during the combustion process. 


\section{Combustion efficiency}

Figure (4) shows the increase in the combustion efficiency with increasing forward speed. The values of combustion efficiency for both jojoba blends (J40 and J60) are lower than that for diesel fuel. Due to the higher viscosity of these blends which causes limited atomization and distribution which affects the combustion efficiency and decreases the oxidization rate. The maximum value of combustion efficiency was observed with jojoba blend (J20) at second gear $(2.6 \mathrm{~km} / \mathrm{h})$, which may be due to the beneficial effect of J20 as an oxygenated fuel catalyst as mentioned before with improving the thermal efficiency.

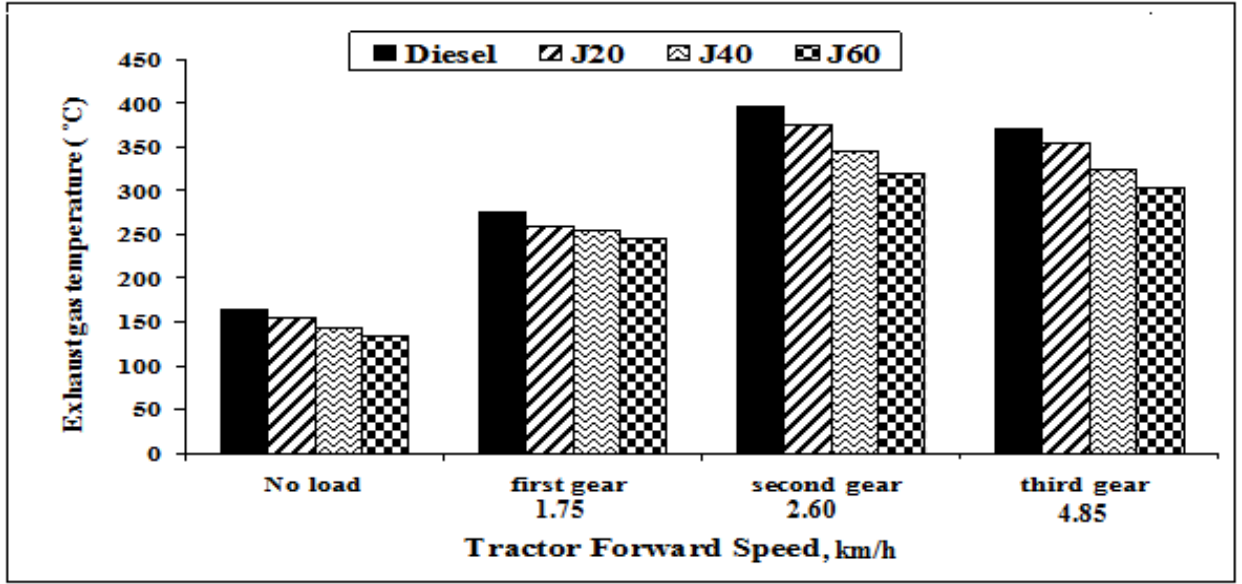

Fig. 3. The variation of exhaust gas temperature versus tractor forward speed for diesel fuel and different blends of jojoba

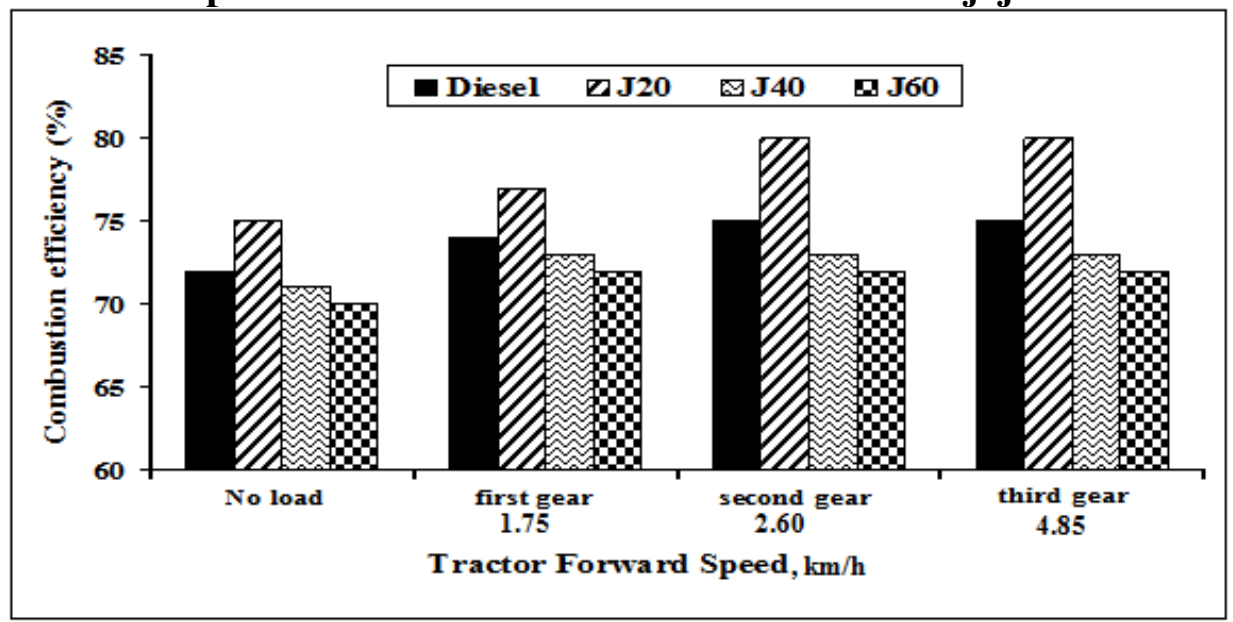

Fig.4. The variation of combustion efficiency versus tractor forward speed for diesel fuel and different blends of jojoba 


\section{Carbon monoxide emission}

Carbon monoxide (CO) emission is a measure of incomplete combustion due to either inadequate oxygen or insufficient time for the completion of the reaction. The variation in the $\mathrm{CO}$ emissions for all tested fuels versus tractor forward speed is shown in Fig. (5). It can be noticed that the CO concentration rate (ppm) was reduced with tractor speed due to the increase in engine temperature which increases oxidization rate of $\mathrm{CO}$ to $\mathrm{CO}_{2}$. The emission values of $\mathrm{CO}$ increased with the increase of jojoba oil percentage in the fuel blend.

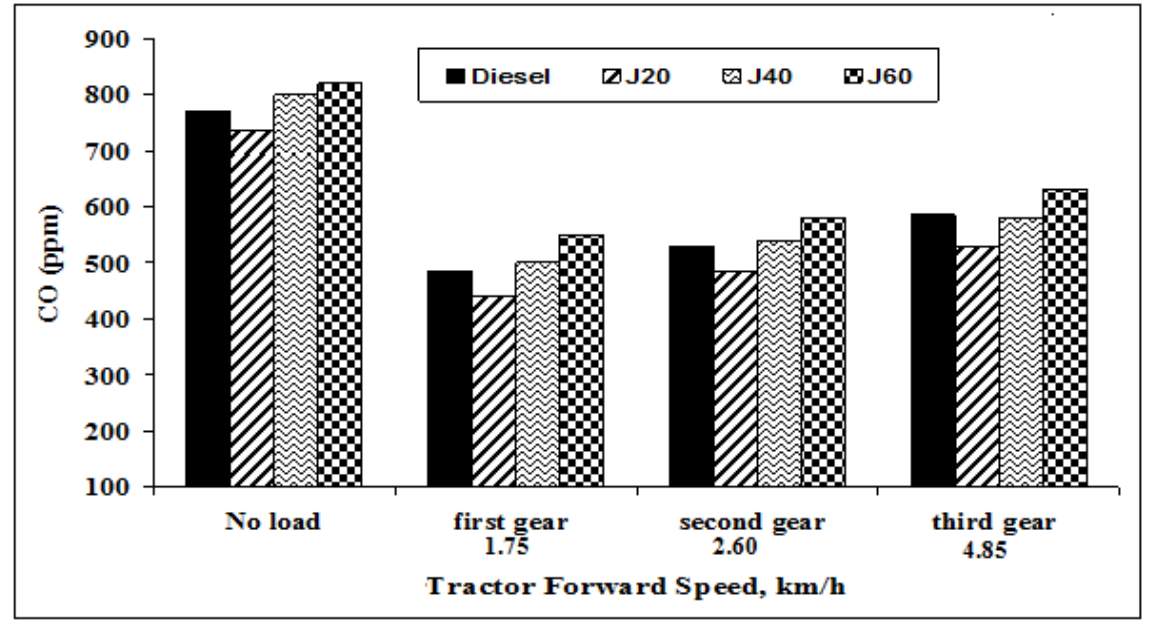

\section{Fig. 5. Effect of tractor forward speed on $\mathrm{CO}$ emissions for diesel fuel and different jojoba blends.}

Fig. (5) shows that whether the tractor was tested on load or no loads condition, $\mathrm{CO}$ concentrations with blends J40 and J60 were slightly higher than that of diesel fuel, due to the higher viscosity of these blends which causes insufficient atomization and distribution. This state affected the combustion efficiency and decreased the oxidization rate to convert all carbon in these blends to carbon dioxide. This result agree with (Herchel et al. 2001), as CO emissions increased when the coconut oil amount increased in the diesel fuel blends, due to the poor spray characteristics of coconut oil, poor mixing, and consequently poor combustion because coconut oil has a viscosity of about 8 times that of diesel fuel. 
For the tests of three forward speeds of tractor concentration of $\mathrm{CO}$ with (J20) was lower than that with pure diesel fuel, which may be due to the beneficial effect of (J20) as an oxygenated fuel.

On the other hand, by increasing jojoba oil percentage in the fuel blends (60\% jojoba), CO concentrations increased due to the negative effect of high viscosity which suppresses the complete combustion process, that produced higher amount of $\mathrm{CO}$. The maximum $\mathrm{CO}$ emissions was produced at no load with J60 blend $(820 \mathrm{ppm})$ compared with that of diesel fuel (770 ppm), while the minimum $\mathrm{CO}$ emissions was produced at the working speeds for J20 (440 ppm) compared with that of diesel fuel (485 ppm). Generally, using 20\% jojoba blend decreased CO concentrations by $9.5 \%$ on average compared with that of diesel fuel.

\section{Unburned hydrocarbons emissions}

The unburned hydrocarbons (HC) emissions with different tractor forward speeds for diesel fuel and different jojoba blends is shown in Fig. (6). The (HC) emissions are produced primarily from the fuel mixed with air surrounding the burning spray which provides lean toward incapability for auto-ignition.

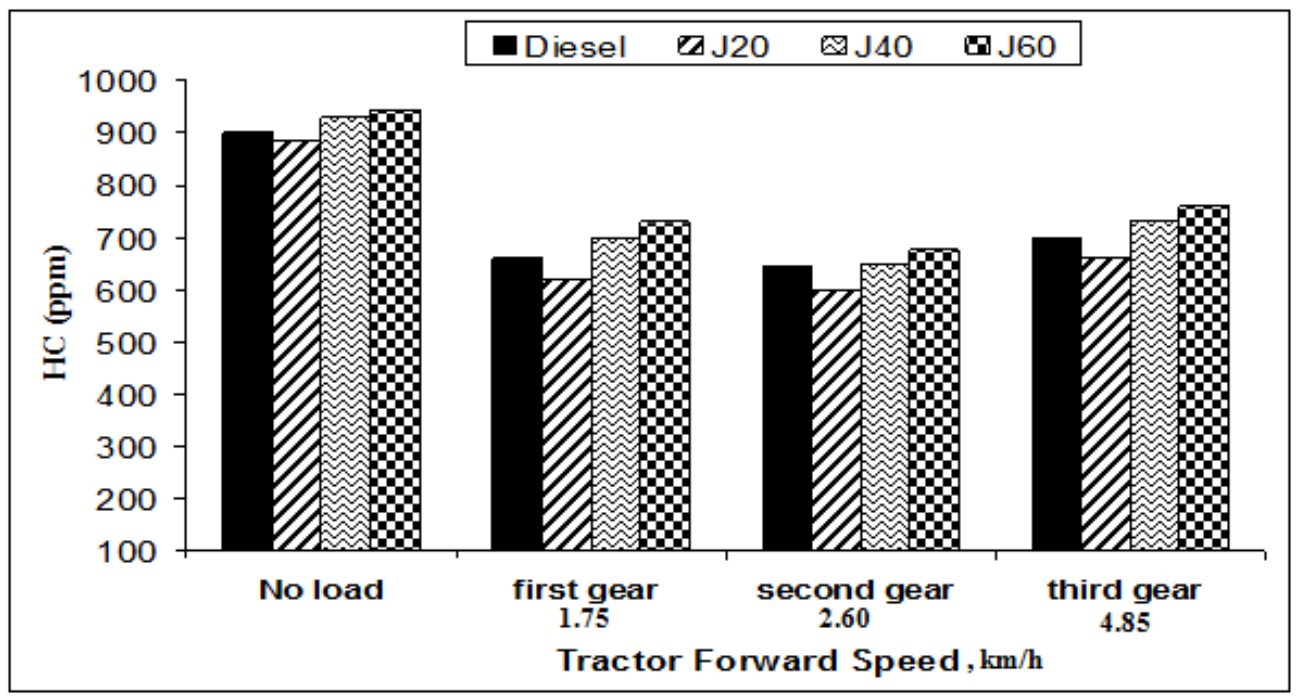

Fig. 6. Effect of tractor forward speed on $\mathrm{HC}$ emissions for diesel fuel and different jojoba blends 
At no load the (HC) emissions were significantly higher than that of other forward speeds. With no load and loads, (HC) concentration for both J40 and J60 jojoba blends were higher than that of pure diesel fuel, due to the higher viscosity of jojoba oil which causes poor atomization and distribution of the blends. While at the three forward speeds ( $\mathrm{HC}$ ) concentration was less with $\mathrm{J} 20$ blend compared with that of petroleum diesel fuel, which may be due to the beneficial effect of J20 as an oxygenated fuel as mentioned before. Generally, hydrocarbon concentrations decreased by $7 \%$ when using J20 comparing with that of pure diesel fuel.

\section{Carbon dioxide emissions}

The carbon dioxide $\left(\mathrm{CO}_{2}\right)$ emissions with different tractor forward speeds for diesel fuel and different jojoba blends is shown in Fig. (7). It can be observed that for jojoba blends and diesel fuel, the amount of $\mathrm{CO}_{2}$ in the exhaust gases increases with the increase at tractor forward speeds. The increase of $\mathrm{CO}_{2}$ in the exhaust gases is accompanied by a decrease in the values of $\mathrm{CO}$ and $\mathrm{O}_{2}$. This may be attributed to the increase in engine temperature due to the increase of tractor forward speed and consequently the increase of oxidization rates during combustion process. It should be mentioned that the formation of $\mathrm{CO}_{2}$ is an exothermic reaction. The values of $\mathrm{CO}_{2}$ emission using $\mathrm{J} 20$ blend is lower than that of diesel fuel at tractor forward speeds. Due to the fact that jojoba oil has low carbon content and has oxygen atoms in the molecule composition, which lead to produced fewer amounts of $\mathrm{CO}_{2}$ emissions than that of pure diesel fuel.

On the other hand, the values of $\mathrm{CO}_{2}$ concentration when using $\mathrm{J} 40$ and J60 blends were observed to be lower than that of diesel fuel and J20 blend at tractor forward speeds due to the incomplete combustion as explained earlier. The maximum $\mathrm{CO}_{2}$ emission produced at tractor forward speeds with $\mathrm{J} 20$ (4.7\%) comparing with pure diesel fuel (5.8\%), while the minimum $\mathrm{CO}_{2}$ emissions were produced at no load for $\mathrm{J} 20$ $(2.4 \%)$ as compared with pure diesel fuel $(2.8 \%)$. When using $20 \%$ jojoba blend, $\mathrm{CO}_{2}$ concentration decreased by $15 \%$ on average compared with that of petroleum diesel fuel. 


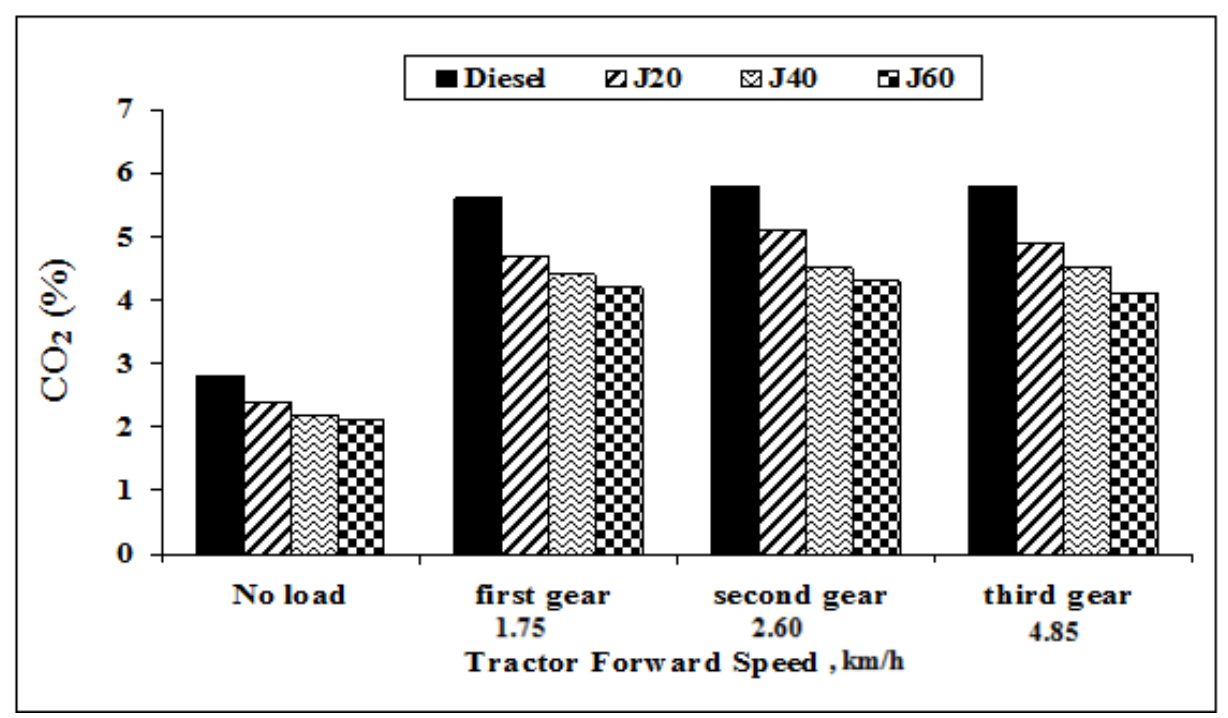

Fig. 7. Effect of tractor forward speed on $\mathrm{CO}_{2}$ emissions for diesel fuel and different jojoba blends

The obtained results supported by Hebbal et al. (2006) who found that maximum brake thermal efficiency was relayed after conducted experiments on diesel engine using non-edible vegetable oil as alternate fuels. Also, Agarwal (2007) and Agarwal and Agarwal (2007) and Agarwal et al., (2008) found that using of biodiesel in conventional diesel engines resulted substantial reduction in emission of unburned hydrocarbons, carbon monoxide and particulate.

\section{Oxygen gas emissions}

The oxygen $\left(\mathrm{O}_{2}\right)$ gas emissions with different tractor forward speeds for diesel fuel and different jojoba blends are shown in Fig. (8). When the tractor runs at no load the values of $\mathrm{O}_{2}$ emission is higher when using $\mathrm{J} 20$ as compared to that of pure diesel fuel. When the tractor runs at forward speeds, the value of $\mathrm{O}_{2}$ emission using $\mathrm{J} 20$ is still relatively higher as compared to that of pure diesel fuel. This may indicate higher oxidization rates of unburned hydrocarbons using J20 blend. On the other hand, the values of $\mathrm{O}_{2}$ emission remains practically constant with the increase of jojoba percentage in the fuel blend, however the values of $\mathrm{O}_{2}$ concentration for all jojoba blends was higher than that of pure diesel 
mainly because of jojoba oil blends have the oxygen atom present in the blends molecules, which would lead to significant increase in the concentration of oxygen gas.

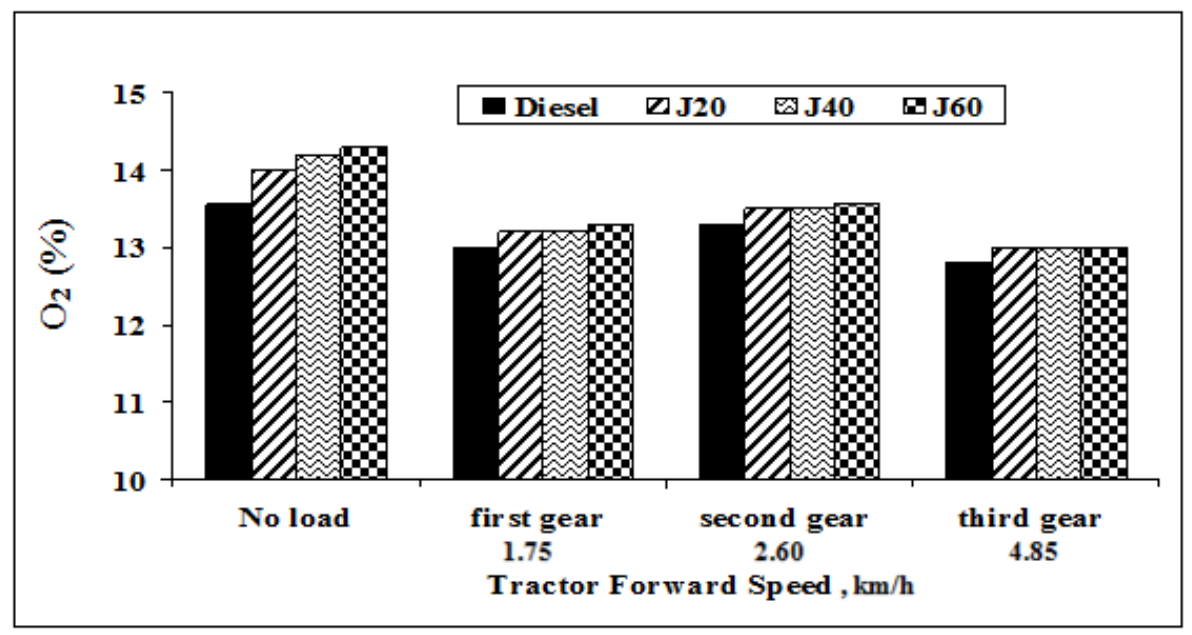

Fig. 8. Effect of tractor forward speed on oxygen concentrations for diesel fuel and different jojoba blends

\section{Oxides of nitrogen emissions}

The NOx emissions are the most harmful gaseous emissions from engines. The nitrogen oxides (NOx) emissions with different tractor forward speeds for diesel fuel and different jojoba blends are shown in Fig. (9). The NOx emissions formed in engine exhaust depend on the high pressure and combustion temperature along with excessive oxygen atoms in air present in combustion chamber, particularly in diesel engine. Fig. (9) shows that the NOx emissions decrease at no load for both pure diesel and all jojoba blends. This is primarily due to the lower burning gas temperature and a lower mass flow rate of intake air on tractor engine. The NOx emissions using jojoba-diesel blends are generally lower than pure diesel fuel due to lower gas temperature as compared with diesel fuel. Jojoba oil does not contain aromatic compound which increase NOx. This rustles are in contrast with that of Heilweil (1988), who proved that aromatic and Poly-aromatic hydrocarbons are responsible for high $\mathrm{NO}_{\mathrm{X}}$ emissions. This is probably due to the higher flame temperatures associated with aromatic compounds. 


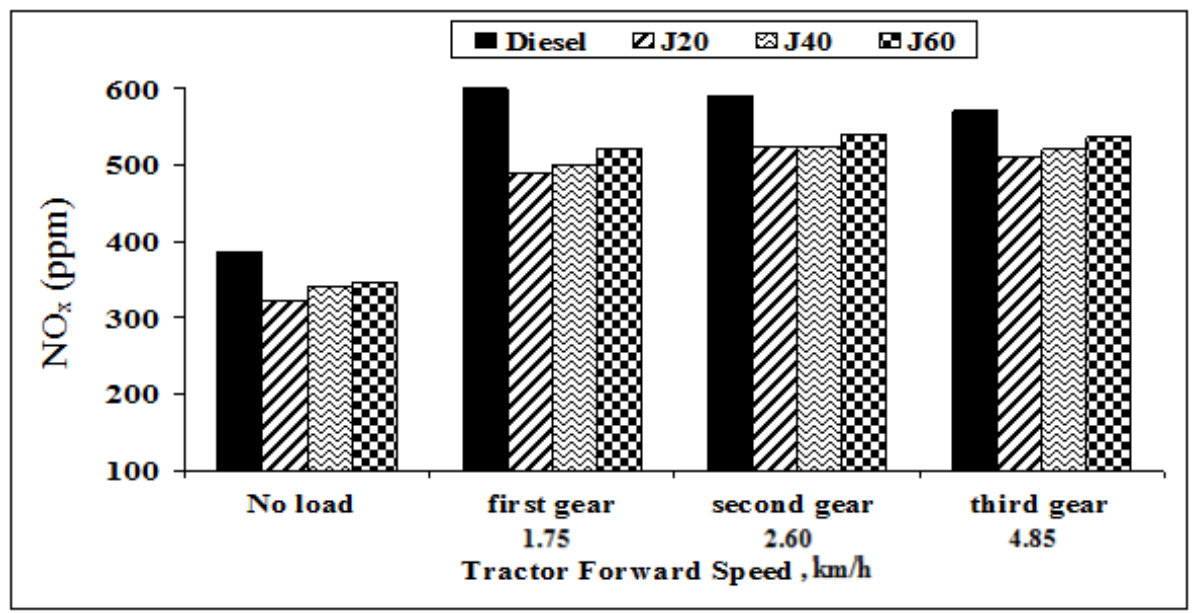

Fig. 9. The variation of NOx emission versus tractor forward speed for diesel fuel and different jojoba blends

A marked reduction in $\mathrm{NO}_{\mathrm{X}}$ emission has been observed when using $\mathrm{J} 20$ at tractor forward speeds, since the $\mathrm{NO}_{\mathrm{X}}$ emission is reduced to $17 \%$ on average. This was due to improving combustion efficiency and engine thermal efficiency for J20 as compared to pure diesel fuel and others blends of $\mathrm{J} 40$ and $\mathrm{J} 60$.

The lowest $\mathrm{NO}_{\mathrm{X}}$ emissions value $(320 \mathrm{ppm})$ was observed at no load when J20 was used, while its value was 386 ppm $\mathrm{NO}_{\mathrm{X}}$ emissions for that of pure diesel fuel. From this result the emission character of $\mathrm{NO}_{\mathrm{X}}$ for jojoba oil blends is a very useful character for the application of jojoba oil and its blends as alternative fuel for diesel engines and could be used as a substitution for diesel fuel.

\section{Sulfur dioxide emissions}

The sulfur dioxides $\left(\mathrm{SO}_{2}\right)$ are pollutant gases that contribute to the formation of acid rain, ozone and smog. Sulfur dioxide combines with water vapor in the exhaust to form a sulfuric acid. Airborne sulfuric acid is a pollutant in fog, smog and acid rain, ending up in the environment degradation. As well as sulfur dioxide itself is corrosive and cause wear of engine parts. It was found that jojoba blends produces lower sulfur dioxides emissions compared to that of pure diesel fuel. 
Fig. (10) shows the variation of sulfur dioxide $\left(\mathrm{SO}_{2}\right)$ emission at different tractor forward speed for pure diesel fuel and different jojoba blends. It can be observed from the figure that $\mathrm{SO}_{2}$ concentration using jojobadiesel blends are generally lower than that of pure diesel fuel due to jojoba oil has no any sulfur content, while diesel fuel has aromatic content of sulfur content.

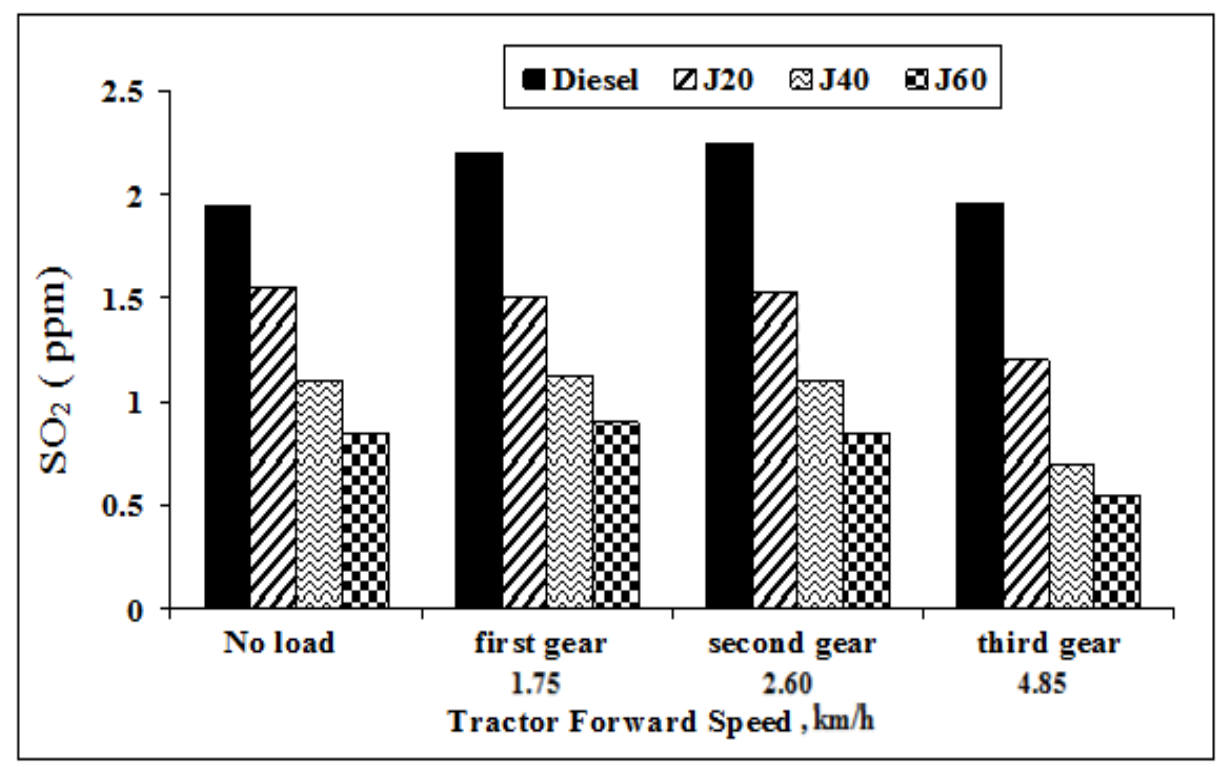

Fig. 10. The variation of $\mathrm{SO}_{2}$ emission versus tractor forward speed for diesel fuel and different jojoba blends

The emission values of $\mathrm{SO}_{2}$ decrease with the increase of jojoba oil percentage in the fuel blend. The highly reduction in $\mathrm{SO}_{2}$ emission was observed $\mathrm{J} 60$ blend where reduction ratio reached to $70 \%$. While using blends $\mathrm{J} 40$ and $\mathrm{J} 20$, the reduction of $\mathrm{SO}_{2}$ emissions were $50 \%$ and $30 \%$, respectively.

From the previous results blending of jojoba oil with diesel fuel is effective solution to reduce sulfur emissions for the environmental protection as well as lengthening engine life on long term. 


\section{CONCLUCSION}

Jojoba oil blends with diesel fuel improve the performance of diesel engine by improving the engine combustion efficiency. The recommended ratio of jojoba-diesel 20\% (J20) is the most efficient blende ratio in reducing the emission of toxic gases as $\mathrm{CO}, \mathrm{NO}_{\mathrm{X}}, \mathrm{THC}$ and $\mathrm{SO}_{2}$ which have positive hygienic effect on the environment.

\section{REFERENCES}

Agarwal, A. K. (2007). Biofuels (alcohols and biodiesel) applications as fuels for internal combustion engines. Progress in Energy and Combustion Science, 33: 233-271.

Agarwal, D. and Agarwal, A. K. (2007). Performance and emissions characteristics of Jatropha oil (preheated and blends) in a direct injection compression ignition engine. Applied Thermal Engineering, 27:2314-2323.

Agarwal, D.; Kumar, L. and Agarwal, A. K. (2008). Performance evaluation of a vegetable oil fuelled compression ignition engine. Renewable Energy, 33:1147-1156.

Alton, R.; Cetinkaya, S. and Yucesu, H. S. (2001). The potential of using vegetable oil fuels as fuel for diesel engines. Energy Conversion and Management, 42:529-538.

ASTM. (2008). American Society for Testing and Materials. International Standards Worldwide. <www.astm.org> (accessed at 31/03/09).

Demirbas, A. (2007). Importance of biodiesel as transportation fuel. Energy Policy, 35: 4661-4670.

Hebbal O. D., Vijaya Kumar Reddy K. and Rajagopal K. (2006). Performance characteristics of a diesel engine with Deccan Hemp oil. Fuel.(42), 45 - 52 . 
Heilweil, I. J. (1988). Review of lubricant properties of jojoba oil and its derivatives. J. Am. Oil Chem. Soc., 65(1):32-3.

Herchel, T. M.; Matsumoto,Y.; Ohkawara, C.; Shiga, S.; Karasawa, T. and Nakamura, H. (2001). The effect of coconut oil and diesel fuel blends on diesel engine performance. JSAE Review, 22:349355 .

INP (Institute of National Planning). (2008). Annual report: Egyptian economy 2006/2007. Cairo, Egypt, 65p.

Martyr, A J. and Plint, M A. (2007). Engine testing: Theory and Practice. Linacre House, Oxford, 442 p.

Peterson, C. L.; Wagner, G. L. and Auld, D. L. (1983). Vegetable oil substitutes for diesel fuel. Transactions of the ASAE, 26(2): 322327.

Peterson, C.L. (1986). Vegetable oil as a diesel fuel: status and research priorities. Transactions of the ASAE, 29(5):1413-1422.

Pramanik, K. (2003). Properties and use of jatropha curcas oil and diesel fuel blends in compression ignition engine. Renewable Energy, 28:239-248.

Ramadhas, A.S. ;Jayaraj, S. and Muraleedharan, C.(2004). Use of vegetable oils as I.C. engine fuels-A review. Renewable Energy, 29: 727-742.

Salem, A.E. (2000). Synthesis of extreme pressure petroleum additive from local jojoba oil. In: The $12^{\text {th }}$ International Seminar, New Trends in Engine and Industrial Lubricants, Fuels, Chemicals and Additives, Cairo. Egypt. Cited by Huzayyin et al. (2004).

Tahir, A. R.; Lapp, H. M. and Buchanan, L. C. (1982). Sunflower oil as a fuel for compression ignition engines. Vegetable Oil Fuels: 
Proceedings of the International Conference on Plant and Vegetable Oils Fuels. St. Joseph, MI: ASAE, pp.82-91.

World Energy Outlook (2016). OECD / IEA, International Energy Agency 9 rue de la Fédération 75739 Paris Cedex 15, France. www.iea.org / Online bookshop

$$
\text { المـلخـص العـربي }
$$

تأثير مخلوط زيت الجوجوبا مع وقود الديزل على الإحتراق وغازات العادم لمحركات جرارات الديزل

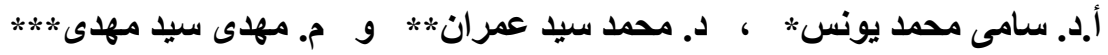

يو اجه العالم فى العصر الحالى أزمات خاصة بتز ايد الطلب على الطاقة ، وإرتفاع أسعار المواد الغذائية ، وتدهور البيئة المحيطة بالإنسان. ونرجع غالبية هذه الأزمات إلى زيادة معدلات إستهلاك الوقود الأحفورى وتزداد خطورة الأزمة بقرب نضوب هذا الوقود ، لذلك أجريت هذه

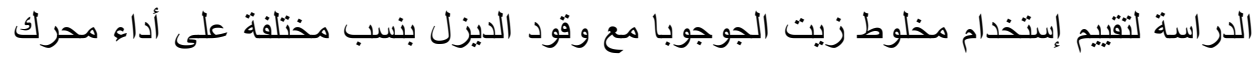
جر ار ديزل ومدى تأثيره على البيئة المحيطة.

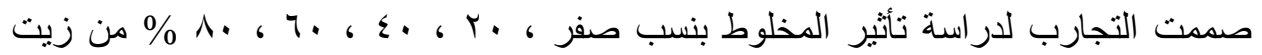

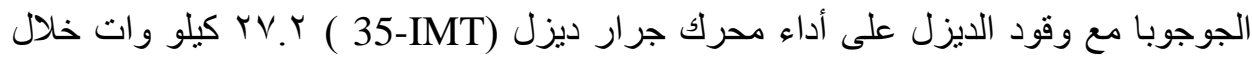
عملية الحرث بمحراث حفار 9 سلاح فى محطة إختبار ات الجرارات بمعهد بحوث الهندسة

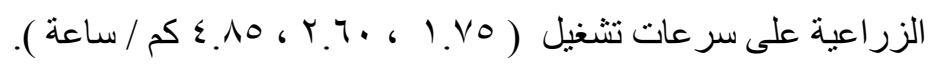

وتم إختيار زيت الجوجوبا لأنه يزرع تحت ظروف متباينه من خطوط العرض و الطول ويتحمل الملوحة وليس من زيوت المائدة لأنه زيت شمعى وليس من مكوناته الروابط الهيدروكربونية الثنانية.

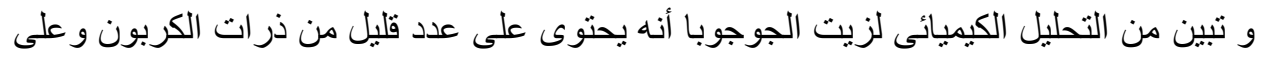
ذرات الأكسجين مما يجعله عامل مؤكسد لغازات نواتج الإحتراق مثل غاز أول أكسيد الكربون و أكاسبد النيتروجين و أكاسبد الكبريت.

* أستاذ الهندسة الزراعية ـ كلية الزراعة ـ جامعة القاهرة . ** أستاذ مساعد ـ قسم الهندسة الزراعية ـ كلية الزراعة - جامعة القاهرة . *** معيد بقسم الهندسة الزراعية ـ كلية الزراعة - جامعة القاهرة . 


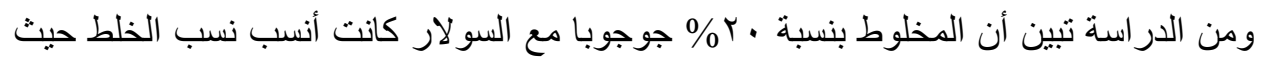

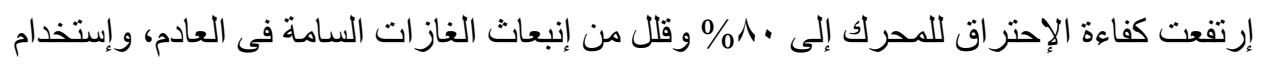

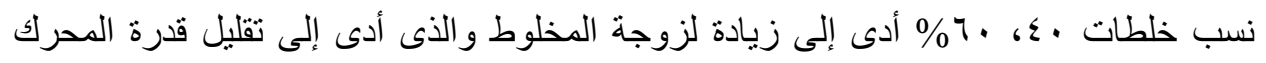

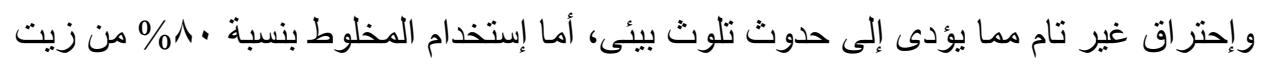

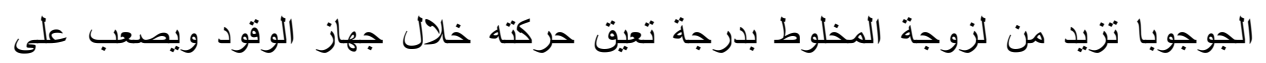
الرشاش تذريته ولذلك تم إستبعادها من الدر اسة.

التوصيات:

من الدراسة تبين أن مخلوط زيت الجوجوبا مع وقود الديزل يحسن من أداء محركات الديزل

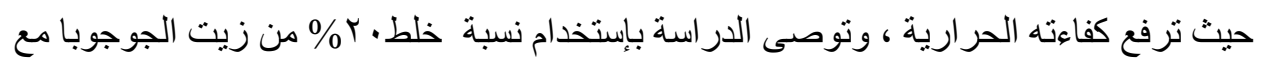

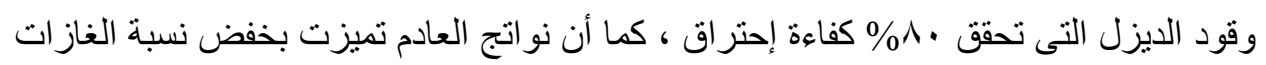
السامة و التى لها تأثير إيجابى صحى على البيئة المحيطة. 